\title{
Penerapan Strategi Pembelajaran Preview Question Read Reflect Recite Review Untuk Meningkatkan Keterampilan Membaca Pemahaman Teks Eksplanasi
}

\author{
${ }^{1}$ Susi Alawiyah \\ ${ }^{1}$ SMK Negeri 5 Kabupaten Tangerang \\ alawiyahsusi@gmail.com
}

\section{ARTICLE INFO \\ Article History: \\ Received : 18-09-2019 \\ Revised : 02-11-2019 \\ Accepted : 15-11-2019 \\ Online : 30-11-2019}

Keywords:

Preview Question Read

Reflect Recite Review;

Teks Eksplanasi

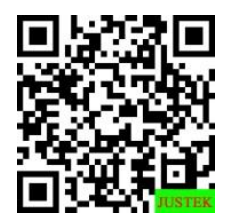

\begin{abstract}
Abstract: This study aims to determine the effect of implementing the $P Q 4 R$ learning strategy on reading comprehension skills of explanatory text. This research was conducted at SMK N 5 Tangerang Regency. The population in this study were all students of SMKN 5 Tangerang Regency. The sample of this study were students of grade 12 TBSM 1 and grade 12 TBSM 2. The approach used in this study was a quantitative approach. This research design uses a control group pretest-posttest design so it requires a control group and an experimental group. The results of this study indicate that the average increase in the application of the PQ4R learning strategy is 25.71 while the average increase in the conventional learning strategy is 15.87. This means that the application of the PQ4R strategy can improve students' reading comprehension skills of explanatory text more effectively when compared to conventional learning strategies at SMK N 5 Tangerang Regency.
\end{abstract}

\begin{abstract}
Abstrak: Penelitian ini bertujuan untuk mengetahui pengaruh penerapan strategi pembelajaran PQ4R terhadap keterampilan membaca pemahaman teks ekplanasi. Penelitian ini dilakukan di SMK N 5 Kabupaten Tangerang. Populasi dalam penelitian ini adalah seluruh Siswa SMK N 5 Kabupaten Tangerang. Sampel penelitian ini adalah siswa kelas 12 TBSM 1 dan kelas 12 TBSM 2. Pendekatan yang digunakan dalam penelitian ini adalah pendekatan kuantitatif. Desain penelitian ini menggunakan desain control group pretest-postest design sehingga memerlukan kelompok kontrol dan kelompok eksperimen. Hasil dari penelitian ini menunjukkan bahwa kenaikan rata-rata penerapan strategi pembelajaran $\mathrm{PQ} 4 \mathrm{R}$ adalah 25.71 sedangkan kenaikan rata-rata strategi pembelajaran konvensional sebesar 15.87. Artinya penerapan strategi PQ4R dapat meningkatkan keterampilan membaca pemahaman teks eksplanasi peserta didik lebih efektif jika dibandingkan dengan strategi pembelajaran konvensional di SMK N 5 Kabupaten Tangerang.
\end{abstract}

\section{A. LATAR BELAKANG}

Pada tahun 1928 pemuda-pemuda Indonesia melakukan sumpah pemuda yang antara lain sumpah pemuda tersebut menyatakan bahwa berbahasa satu Bahasa Indonesia. Dari pernyataan pemuda Indonesia saat itu dapat diartikan bahwa Bahasa adalah salah satu pemersatu bangsa Indonesia. Bahasa adalah sebagai alat komunikasi. Seseorang yang mampu memahami Bahasa akan sangat mudah menyampaikan ide, dan gagasan kepada publik. Kemampuan berbahasa sangat penting dikuasai oleh peserta 
didik terutama dalam pergaulan internasional. Peserta didik diwajibkan untuk memiliki keterampilan berbahasa. Keterampilan berbahasa yang wajib dimiliki oleh peserta didik meliputi keterampilan menyimak, keterampilan berbicara, keterampilan membaca dan keterampilan menulis. Menurut (Saddhono, 2012) setiap kegiatan belajar mengajar, empat keterampilan berbahasa yaitu keterampilan menyimak, keterampilan berbicara, keterampilan membaca, dan keterampilan menulis selalu muncul. Menurut (Hesti Indah Mifta Nur'aini, Kundharu Saddhono, 2015) kegiatan pembelajaran bahasa Indonesia peserta didik diarahkan untuk dapat menguasai empat keterampilan berbahasa, yaitu keterampilan menyimak, keterampilan membaca, keterampilan berbicara, dan keterampilan menulis. Keterampilan berbahasa menurut (Wulandari et al., 2015) dikelompokkan menjadi dua, yaitu keterampilan berbahasa lisan dan keterampilan berbahasa tulis. Keterampilan berbahasa lisan meliputi keterampilan menyimak dan keterampilan berbicara, sedangkan keterampilan berbahasa tulis meliputi keterampilan membaca dan keterampilan menulis.

Menurut (Henry Guntur Tarigan, 2013) membaca adalah suatu proses yang dilakukan untuk mendapatkan pesan, yang ingin disampaikan oleh penulis melalui media katakata/bahasa tulis. (Aminudin, 2010) mengemukakan bahwa membaca disebut sebagai kegiatan memberikan reaksi karena dalam membaca seseorang terlebih dahulu melaksanakan pengamatan terhadap huruf sebagai representasi bunyi ujaran maupun tanda penulisan lainnya. Menurut (Abidin, 2012) membaca pemahaman dapat pula diartikan sebagai suatu proses yang dilakukan dengan sungguh-sungguh oleh pembaca untuk mendapatkan makna, pengetahuan dan informasi yang tersirat atau tersurat dalam sebuah bacaan.

Berdasarkan jenisnya membaca pemahaman dapat dikelompokkan menjadi empat (Somadayo, 2011) yaitu; 1) pemahaman Literal, membaca pemahaman literal adalah membaca teks bacaan dan mengerti tentang isi bacaan, makna bacaan serta maksud dan tujuan. Menurut (Somadayo, 2011) membaca pemahaman literal adalah memahami makna, maksud dan tujuan yang ingin disampaikan oleh penulis melalui teks bacaan, 2) Pemahaman Interpretatif, menurut (Dalman, 2014) membaca pemahaman interpretative yaitu suatu aktifitas membaca yang mengarapkan peserta didik mampu mengartikan maksud dan tujuan penulis, apakah itu berkaitan dengan bacaan fiksi atau fakta, karakter tokoh, reaksi emosional, Bahasa yang digunakan, majas, peribahasa serta dampak cerita, 3)Pemahaman Kritis, membaca pemahaman kritis menuntut pembaca untuk mampu membandingkan, menganalisa dan menemukan makna tentang gagasan utama, fakta serta peristiwa yang disajikan dalam teks bacaan yang kemudian dikritisi berdasarkan pengetahuan dan pengalaman pembaca, 4) pemahaman Kreatif, menurut (Somadayo, 2011) seseorang dikatakan memiliki pemahaman membaca kreatif jika dapat memenuhi kriteria yaitu, seperti berikut. 1) Kegiatan membaca tidak berhenti sampai pada saat menutup buku. Pembaca masih mampu mengingat dan bisa menceritakan kembali tentang isi buku yang dibaca tersebut, 2) Mampu menerapkan hasil untuk kepentingan hidup sehari-hari. Seseorang setelah selesai membaca mampu mempraktekkan ilmu yang didapatkan kedalam kehidupan nyata baik untuk kepentingan sendiri maupun orang lain, 3) munculnya perubahan sikap dan tingkah laku setelah proses membaca selesai. Seseorang setelah membaca pemahaman kreatif ini dapat mengambil makna dari tulisan tersebut sehingga secara perlahan perilaku dan kebiasaan pembaca menjadi berubah sesuai dengan harapan penulis buku tersebut; 1) hasil membaca berlaku sepanjang masa. Pemahaman membaca kreatif mengilhami seseorang untuk mempraktekkan ilmu yang didapatkan kedalam kehidupan sehari-hari sepanjang hidupnya, 2) mampu menilai secara kritis dan kreatif bahan-bahan bacaan. Hasil dari membaca pemahaman kreatif 
pembaca mampu untuk menilai tentang isi buku dan materi bacaannya, 3) mampu memecahkan masalah kehidupan sehari-hari berdasarkan hasil bacaan yang telah dibaca. Buku yang baik dan dihayati oleh pembaca maka isi buku tersebut merupakan salah satu solusi untuk memecahkan persoalan dalam kehidupan sehari-hari seseorang.

Penilaian keterampilan membaca pemahaman menurut (Nurgiyantoro, 2015) dapat dilakukan dengan du acara yaitu penilaian penceritaan kembali dan penilaian penulisan kembali. Penilaian penceritaan kembali dilakukan dengan secara lisan. Peserta didik menceritakan kembali apa yang telah dibaca. Penilaian penulisan kembali peserta didik menuliskan kembali cerita yang telah dibaca dengan menggunakan kalimat-kalimat yang mudah dipahami.

Kriteria penilaian penulisan kembali cerita menurut (Nurgiyantoro, 2015) adalah, 1) pemahaman dan ketepatn isi, peserta didik menuliskan kembali teks eksplanasi yang telah dibaca dengan ringkas dan runtut serta tidak mengurangi kandungan makna teks sebenarnya, 2) ketepatan organisasi teks, peserta didik menuliskan kembali teks tersebut secara ringkas sesuai dengan pola kalimat yang diinginkan penulis, 3) ketepatan diksi, penulisan kembali teks eksplanasi disajikan dengan pemilihan kata yang dapat mewakili keadaan sesungguhnya, 4) ketepatan struktur kalimat, peserta didik menuliskan kembali cerita tersebut tetap memperhatikan struktur kalimat, 5) ejaan dan tata Bahasa, penulisan kembali teks tersebut, harus memperhatikan ejaan dan tata tulis menurut kaidah Bahasa Indonesia yang benar, dan 6) kebermaknaan penceritaan, penulisan kembali teks eksplansi tidak merubah makna dalam tulisan aslinya.

Teks eksplanasi merupakan teks yang menggambarkan suatu peristiwa, baik itu peristiwa alam, ilmu pengetahuan, sosial, budaya, dan lainnya. Teks eksplanasi berisi fakta yang dapat menjawab pertanyaan tentang "bagaimana" dan "mengapa" suatu persitiwa terjadi. Tujuan utama teks eksplanasi adalah untuk menjelaskan proses dan sebab terjadinya suatu peristiwa. Penjelasan yang disampaikan dalam teks eksplanasi berdasarkan bidang keilmuan (bersifat ilmiah) yang mengacu pada fakta, realita, teori, dan hasil penelitian yang dilakukan oleh ilmuwan.

Strategi pembelajaran merupakan cara untuk menyampaikan kepada peserta didik agara peserta memahami materi pelajaran. Strategi pembelajaran yang tepat dapat meningkatkan pemahaman peserta didik. (Khanifatul, 2012) menyatakan bahwa strategi pembelajaran merupakan proses penentuan rencana yang berfokus pada tujuan disertai penyusunan suatu cara agar tujuan tersebut dapat dicapai. Menurut (Hamzah B Uno, 2014) metode PQ4R merupakan salah satu bagian metode elaborasi. Metode elaborasi adalah proses penambahan penilaian, sehingga informasi baru akan menjadi lebih bermakna. Metode ini digunakan untuk membantu siswa mengingat apa yang dibaca dengan tujuan untuk mempelajari sampai tuntas bab demi bab suatu buku pelajaran. Menurut (Wassid, 2011) strategi elaborasi PQ4R dapat membantu pemindahan informasi baru dari memori di otak yang bersifat jangka pendek ke jangka panjang dengan menciptakan hubungan dan gabungan antara informasi baru dengan informasi yang telah ada. Jadi, peserta didik dapat menghafal atau mengingat dengan pasti informasi yang telah dibacanya.

Langkah-langkah yang harus dilakukan dalam metode PQ4R adalah sebagai berikut: 1) Preview, langkah preview ini ditujukan agar peserta didik membaca selintas dengan cepat sebelum kegiatan membaca bahan bacaan. Peserta didik dapat memulai dengan membaca tema, sub tema, judul dan sub judul, kalimat-kalimat permulaan atau akhir suatu paragraf atau ringkasan pada akhir suatu bab, 2) Question, langkah question adalah peserta didik diminta mengajukan pertanyaan-pertanyaan kepada diri sendiri. Peserta didikdapat memmahami bacaan lewat judul, sub judul, topik sub topik. Pengalaman ini akan memberikan pemahaman baru kepada peserta didik, 3) Read, langkah ketiga yaitu 
peserta didik membaca teks eksplanasi secara intensif, yaitu peserta didik harus memberikan catatan-catatan singkat terhadap teks yang dibacanya, 4) Reflect, langkah reflect ini merupakan satu kesatuan komponen esensial dari ketiga langkah tersebut. Selama membaca peserta didik tidak hanya cukup mengingat atau menghafal, tetapi peserta didik harus mampu (a) menghubungkan informasi, (b) menghubungkan subtopik-subtopik, (c) mencoba memecahkan kontradiksi, dan (d) mencoba menggunakan materi itu untuk memecahkan masalah, 5) Recite, pada langkah kelima ini, peserta didik diminta untuk merenungkan (mengingat) kembali informasi yang telah ddibaca. Peserta didik mampu menjawab pertanyaan-pertanyaan yang telah dibuat, dan 6) Review, pada langkah terakhir ini peserta didik diminta untuk membaca catatan yang dibuat dan jika diperlukan membaca kembali pertanyaan dan jawaban yang telah dibuat.

Strategi pembelajaran PQ4R (Preview, Question, Read, Reflect Recite, Review) menurut (Trianto, 2012) merupakan salah satu bagian dari strategi elaborasi yang membantu pemindahan informasi baru dari memori jangka pendek ke memori jangka panjang dengan menambahkan perincian informasi baru melalui tahap Preview (membaca selintas), Question (bertanya), Read (membaca), Reflect (refleksi), Recite (tanya jawab sendiri), dan Review (mengulang secara menyeluruh).

Penelitian tentang metode PQ4R telah banyak dilakukan. Penelitian (Linayaningsih, 2011) menyimpulkan bahwa metode PQ4R dapat meningkatkan prestasi belajar pendidikan kewarganegaraan. Penelitian (Dwi Eka Martina, Iskandar As, 2018) metode PQ4R mampu meningkatkan pemahaman bacaan siswa, sehingga guru dianjurkan untuk menggunakan metode ini dalam pembelajarannya. Penelitian (Wahyuningsih, 2012) menyatakan bahwa strategi pembelajaran PQ4R dapat menumbuhkan sikap positif siswa untuk membaca dan mempelajari materi sistem saraf yang bersifat abstrak dengan kemauannya sendiri, siswa menjadi pembaca yang efektif, efisien, dan berdampak pada peningkatan minat, aktivitas, dan hasil belajar siswa secara klasikal.

\section{B. METODE PENELITIAN}

Penelitian ini menggunakan pendekatan kuantitatif. Pendekatan kuantitatif dipilih karena pemecahan masalah harus sesuai dengan rumusan masalah yang memerlukan perhitungan serta pengukuran terhadap variabel dan pengujian terhadap hipotesis yang telah ditetapkan. Desain penelitian ini menggunakan desain control group pretest-postest design. Penelitian ini memerlukan kelompok kontrol dan kelompok eksperimen. Kelompok kontrol diperlakukan dengan menggunakan strategi pembelajaran konvensional sedangkan kelompok eksperimen diperlakukan dengan menggunakan strategi pembelajaran PQ4R dalam meningkatkan keterampilan membaca pemahamanan peserta didik. Kedua kelompok diberikan pre-test sebelum diberikan perlakukan.

Populasi dalam penelitian ini adalah seluruh siswa SMK Negeri 5 Kabupaten Tangerang. Sedangkan sampel dalam penelitian ini adalah kelas 12 TBSM 1 sebagai kelompok control dan kelas 12 TBSM 2 sebagai kelompok eksperimen. Jumlah siswa masing-masing kelas tersebut adalah 36 orang. Data berasal dari hasil pre-test dan posttest kelompok kontrol dan kelompok eksperimen.

\section{HASIL DAN PEMBAHASAN}

\section{Deskripsi data}

a) Data Pre-test

Distribusi frekuensi nilai pre-test kelas eksperimen dapat dilihat pada tabel berikut:

Tabel 1. Distribusi frekuensi pre-test kelas eksperimen

\begin{tabular}{|l|l|l|l|}
\hline No & Interval Skor & Frekuensi & $\%$ \\
\hline
\end{tabular}




\begin{tabular}{|c|c|c|c|}
\hline 1 & $0.00-20$ & 0 & 0 \\
\hline 2 & $21-40$ & 12 & $33 \%$ \\
\hline 3 & $41-60$ & 15 & $42 \%$ \\
\hline 4 & $61-80$ & 6 & $17 \%$ \\
\hline 5 & $81-100$ & 3 & $8 \%$ \\
\hline \multicolumn{2}{|c|}{ Jumlah } & 36 & $100 \%$ \\
\hline
\end{tabular}

Distribusi frekuensi nilai pre-test kelas kontrol dapat dilihat pada tabel berikut:

Tabel 2. Distribusi frekuensi pre-test kelas kontrol

\begin{tabular}{|c|c|c|c|}
\hline No & Interval Skor & Frekuensi & $\%$ \\
\hline 1 & $0.00-20$ & 0 & 0 \\
\hline 2 & $21-40$ & 14 & $39 \%$ \\
\hline 3 & $41-60$ & 16 & $44 \%$ \\
\hline 4 & $61-80$ & 4 & $11 \%$ \\
\hline 5 & $81-100$ & 2 & $5 \%$ \\
\hline \multicolumn{2}{|c|}{ Jumlah } & 36 & $100 \%$ \\
\hline
\end{tabular}

Berdasarkan data skor pre-test tersebut diketahui keterampilan pemahaman bacaan peserta didik kelas eksperimen dan kelas kontrol relatif sama.

b) Data post-test

Distribusi frekuensi nilai post-test kelas eksperimen dapat dilihat pada tabel berikut:

Tabel 3. Distribudi frekuensi post-test kelas eksperimen

\begin{tabular}{|c|c|c|c|}
\hline No & Interval Skor & Frekuensi & $\%$ \\
\hline 1 & $0.00-20$ & 0 & 0 \\
\hline 2 & $21-40$ & 1 & $3 \%$ \\
\hline 3 & $41-60$ & 4 & $11 \%$ \\
\hline 4 & $61-80$ & 26 & $72 \%$ \\
\hline 5 & $81-100$ & 5 & $14 \%$ \\
\hline \multicolumn{2}{|c|}{ Jumlah } & 36 & $100 \%$ \\
\hline
\end{tabular}

Distribusi frekuensi nilai post-test kelas kontrol dapat dilihat pada tabel berikut:

Tabel 4. Distribusi frekuensi post-test kelas kontrol

\begin{tabular}{|c|c|c|c|}
\hline No & Interval Skor & Frekuensi & $\%$ \\
\hline 1 & $0.00-20$ & 0 & 0 \\
\hline 2 & $21-40$ & 8 & $22 \%$ \\
\hline 3 & $41-60$ & 16 & $44 \%$ \\
\hline 4 & $61-80$ & 10 & $28 \%$ \\
\hline 5 & $81-100$ & 2 & $5 \%$ \\
\hline \multicolumn{2}{|c|}{ Jumlah } & 36 & $100 \%$ \\
\hline
\end{tabular}

Berdasarkan data tersebut diatas dapat dijelaskan bahwa secara nyata ada perbedaan hasil antara kelas eksperimen dengan kelas kontrol.

\section{Pengujian Prasyarat Analisis}

a. Uji Normalitas

Uji normalitas digunakan untuk menguji variabel penelitian apakah berdistribusi normal atau tidak. Kriteria pengujian adalah jika sig $>0.05$ maka variabel penelitian dinyatakan berdistribusi normal dan jika sig $<0.05$ variabel penelitian dinyatakan berdistribusi normal. Rekapitulasi uji normalitas dapat dilihat pada tabel berikut.

Tabel 5. Rekapitulasi uji normalitas

\begin{tabular}{|c|l|l|l|}
\hline No & Kelompok & sig & Kesimpulan \\
\hline 1 & Pre-test kelas eksperimen & 0.396 & Normal \\
\hline
\end{tabular}




\begin{tabular}{|c|l|l|l|}
\hline 2 & Post-test kelas eksperimen & 0.425 & Normal \\
\hline 3 & Pre-test kelas kontrol & 0.127 & Normal \\
\hline 4 & Post-test kelas kontrol & 0.289 & Normal \\
\hline
\end{tabular}

Berdasarkan data di atas dapat disimpulkan bahwa data pre-test dan post-test kelas eksperimen dan kelas kontrol berdistribusi normal.

b. Uji Homogenitas

Uji homogenitas berfungsi untuk mengetahui kesamaan antara variabel kontrol dengan variabel eksperimen. Kriteria pengujian jika nilai sig $>0.05$ maka variabel dinyatakan homogen, jika sig $<0.05$ maka variabel dinyatakan tidak homogen.

Tabel 6. Uji homogenitas

\begin{tabular}{|l|l|l|}
\hline Kelas & Sig & Kesimpulan \\
\hline Pre-test & 0.247 & Homogen \\
\hline Post-test & 0.359 & Homogen \\
\hline
\end{tabular}

\section{Pengujian Hipotesis}

a. Uji t Pre-test dan Post-test kelas Eksperimen

Tabel 7. Rekapitulasi uji t

\begin{tabular}{|l|l|c|c|c|}
\hline \multicolumn{1}{|c|}{ Kelas } & Rata-rata & $\mathrm{T}$ hitung & $\mathrm{T}$ tabel & $\mathrm{p}$ \\
\hline Pre-test kelas eksperimen & 52.50 & 7.21892 & 2.02809 & 0.000 \\
\cline { 1 - 2 } Post-test kelas eksperimen & 78.21 & & & \\
\hline
\end{tabular}

Dari data diatas dapat disimpulkam bahwa ada peningkatan skor sebesar 25.71 secara signifikan pada kelas eskperimen

b. Uji t Pre-test dan Post-test kelas control

Tabel 8. Rekapitulasi uji t

\begin{tabular}{|l|l|c|c|c|}
\hline \multicolumn{1}{|c|}{ Kelas } & Rata-rata & $\mathrm{T}$ hitung & $\mathrm{T}$ tabel & $\mathrm{p}$ \\
\hline Pre-test kelas kontrol & 51.78 & 6.21892 & 2.02809 & 0.000 \\
\cline { 1 - 2 } Post-test kelas kontrol & 67.65 & & & \\
\hline
\end{tabular}

Dari data diatas dapat disimpulkam bahwa ada peningkatan skor sebesar

15.87 secara signifikan pada kelas kontrol.

c. Uji t Post-test kelas eskperimen dan Post-test kelas kontrol

Tabel 9. Rekapitulasi uji t

\begin{tabular}{|l|l|c|c|c|}
\hline \multicolumn{1}{|c|}{ Kelas } & Rata-rata & $\mathrm{T}$ hitung & $\mathrm{T}$ tabel & $\mathrm{p}$ \\
\hline Post-test kelas eskperimen & 78.21 & 8.6985 & 1.99346 & 0.000 \\
\cline { 1 - 2 } Post-test kelas kontrol & 67.65 & & & \\
\hline
\end{tabular}

Dari data diatas dapat disimpulkam bahwa ada perbedaan peningkatan skor pada kelas kontrol dan kelas eskperimen.

d. Uji t kenaikan Skor

Tabel 10. Rekapitulasi uji t

\begin{tabular}{|l|l|c|c|c|}
\hline \multicolumn{1}{|c|}{ Kelas } & Rata-rata & $\mathrm{T}$ hitung & $\mathrm{T}$ tabel & $\mathrm{p}$ \\
\hline Kelas eskperimen & 25.71 & 8.0456 & 1.99346 & 0.000 \\
\cline { 1 - 2 } Kelas kontrol & 15.87 & & & \\
\hline
\end{tabular}

Dari data diatas dapat disimpulkam bahwa ada perbedaan peningkatan skor yang signifikan pada kelas kontrol dan kelas eskperimen

Hasil penelitian ini sejalan Penelitian (Linayaningsih, 2011) menyimpulkan bahwa metode PQ4R dapat meningkatkan prestasi belajar. Hasil yang sama juga didapatkan dari penelitian (Dwi Eka Martina, Iskandar As, 2018) yang menyatakan bahwa metode PQ4R mampu meningkatkan pemahaman bacaan siswa. Penelitian (Wahyuningsih, 2012) juga 
menghasilkan kesimpulan yang sama bahwa metode PQ4R dapat menumbuhkan sikap positif siswa untuk membaca.

\section{SIMPULAN DAN SARAN}

Berdasarkan data di atas dapat disimpulkan bahwa penerapan strategi pembelajaran PQ4R dapat meningkatkan keterampilan pemahaman bacaan teks eksplanasi pada kelas eksperimen. Strategi pembelajaran ini sangat cocok diterapkan kepada peserta didik yang selama ini kemampuan literasinya masih kurang.Peserta didik merasa tertantang untuk memahami teks eksplanasi dengan strategi pembelajaran PQ4R. Strategi pembelajaran PQ4R dapat meningkatkan keterampilan membaca pemahaman teks eksplanasi sebesar 25.71 sedangkan strategi konvensional sebesar 15.87 artinya strategi PQ4R lebih cocok digunakan jika dibandingkan strategi pembelajaran seramah (konvensional).

Pendidik seharusnya memiliki kemampuan untuk memahami berbagai macam model pembelajaran. Setiap pembelajaran dan pokok bahasan yang berbeda sebaiknya pendidik menggunakan strategi pembelajaran yang berbeda pula. Semakin vaariatif strategi pembelajaran yang dikuasai pendidik akan semakin mudah juga pendidik menyampaikan materi ajarnya.

\section{REFERENSI}

Abidin, Y. (2012). Pembelajaran Bahasa Berbasis Pendidikan Karakter. Bandung: PT. Refika Aditama.

Aminudin. (2010). Pengantar Apresiasi Karya Sastra. Bandung: Sinar Baru Algendindo.

Dalman. (2014). Keterampilan Menulis. In Jakarta: PT. Raja Grafindo Persada.

Dwi Eka Martina, Iskandar As, and Y. (2018). The Effect of Using PQ4R (Preview, Question, Read, Reflect, Recite, Review) Strategy on EFL Students' Reading Comprehension Achievement. Research in English and Education (READ), 3(1), 17-24.

Hamzah B Uno. (2014). Model Pembelajaran. Menciptakan proses Belajar Mengajar Yang Kreatif dan Efektif. Bumi Aksara. Bandung: Bumi AKsara.

Henry Guntur Tarigan. (2013). Berbicara sebagai suatu keterampilan berbahasa. Bandung: Angkasa.

Hesti Indah Mifta Nur'aini, Kundharu Saddhono, C. U. (2015). ( Studi Kasus Di Kelas X SMK Negeri 1 Karanganyar ) Hesti Indah Mifta Nur' aini , Kundharu Saddhono, Chafit Ulya Universitas Sebelas Maret Kurikulum adalah salah satu penentu laju perkembangan serta kemajuan pendidikan. Indonesia hingga tahun 2013 tela. BASASTRA Jurnal Penelitian Bahasa, Sastra Indonesia Dan Pengajarannya Volume 3 Nomor 3, Agustus 2015, ISSN I2302-6405, 3.

Khanifatul. (2012). Pembelajaran Inovatif: Strategi Mengelola Kelas Secara Efektif dan Menyenangkan. In Yogjakarta: Ar-ruzz Media.

Linayaningsih, F. (2011). Metode PQ4R (Preview, Question, Read, Reflect, Recite, Review) Untuk Meningkatkan Prestasi Belajar Pendidikan Kewarganegaraan. Majalah Ilmiah INFORMATIKA, 02(2002), 75-86.

Nurgiyantoro, B. (2015). Teori Pengkajian Fiksi. Cetakan 1X. Yogyakarta: Gajah Mada University Press.

Saddhono, K. (2012). Kajian Sosiolinguistik Pemakai Bahasa Mahasiswa Asing Dalam Pembelajaran Bahasa Indonesia Untuk Penutur Asing (BIPA). Kajian Linguistik Dan Sastra, 24(2), 176-186.

http://journals.ums.ac.id/index.php/KLS/article/view/96/92

Somadayo, S. (2011). Strategi dan Teknik Pembelajaran Membaca. Yogtakarta: Graha Ilmu. 
Trianto. (2012). Model Pembelajaran Terpadu. In (akarta: PT Bumi Aksara.

Wahyuningsih, A. N. (2012). Pengembangan Media Komik Bergambar Materi Sistem Saraf Untuk Pembelajaran Yang Menggunakan Strategi Pq4R. Journal of Innovative Science Education, 1(1), 102-110.

Wassid, I. dan D. S. (2011). Strategi Pembelajaran Bahasa. Bandung: PT Remaja Rosdakarya.

Wulandari, Y., Suryanto, E., \& Saddhono, K. (2015). Penerapan Metode Picture and Picture Untuk Meningkatkan Motivasi Dan Keterampilan Menulis Teks Narasi Pada Siswa Sekolah Menengah Kejuruan. Jurnal Penelitian Bahasa, Sastra Indonesia, Dan Pengajarannya, 3(2), 54514. 